\title{
SEROPREVALENCE OF CHLAMYDOPHILA INFECTION IN SHEEP OF KRISHNA DISTRICT, ANDHRA PRADESH
}

\author{
G. DEEPIKA KUMARI*, R. N. RAMANI PUSHPA AND B. KEERTHI \\ Department of Veterinary Microbiology \\ NTR College of Veterinary Sciences \\ Gannavaram, Andhra Pradesh- 521 102, India
}

\begin{abstract}
The present study was aimed to assess the seroprevalence of chlamydial infection in sheep. Chlamydophila abortus infection is characterized by reproductive losses in livestock posing heavy economic losses to farmers. Occurrence of the disease is high during the lambing season and $C$. abortus efficiently colonizes in the placental trophoblasts causing enzootic abortions. Moreover, it represents a zoonotic risk to humans who come in contact with aborted placental material. The present sero-prervalence study was conducted to identify the presence of chlamydial infection in sheep. A total of 28 serum samples were collected from the aborted cases in Krishna district of Andhra Pradesh. The seroprevalence of chlamydial infection was studied by enzyme linked immonosorbent assay (ELISA) for detection of antibodies in the serum samples of suspected chlamydial infection. Out of 28 serum samples tested, four samples were positive for the Chlamydophila abortus infection in sheep. The percentage of Chlamydophila abortus infection in sheep was 14. The present study indicated the prevalence of bacterial pathogen Chlamydophila abortus infection as a cause of abortions in sheep.
\end{abstract}

Key words: Andhra Pradesh, Chlamydophila abortus, Enzootic abortions, Ruminants, Seroprevalence

Chlamydial organisms, the fastidious obligatory intracellular bacterial pathogens, are responsible for a wide variety of infections in domestic ruminant livestock, mostly the enzootic abortions (Markey, 2011). Chlamydiae are Gram negative diverse group of organisms belonging to the order Chlamydiales and family

*Corresponding Author 
Chlamydiaceae. They were further grouped into two genera viz. Chlamydia and Chlamydophila (Everett et al., 1999). Chlamydophila abortus (C. abortus) causes mastitis, epizootic bovine abortions in milking animals, endometritis, vaginitis, pneumonia, enteritis, conjunctivitis, encephalitis, (Twomey et al., 2003) and localized infections like polyarthritis, orchitis, epididimytis and vesiculitis (Gomes et al., 2001; Rekiki et al., 2002).

Chlamydiae is also responsible for zoonosis in humans without the need of any intermediate host and causes abortions in pregnant women (Rodolakis and Mohamad, 2010). The aborted fetus, placenta and uterine discharges contains the elementary bodies which upon ingestion through contaminated feed and water is also responsible for the occurrence of disease (DeGraves et al., 2004). Affected animals act as latent carriers with chances of abortions in the subsequent gestation period and remain as carriers for lifetime (Koehler et al., 1997). Chlamydophila abortus is the causative pathogen for enzootic abortions in ewes and responsible for $20 \%$ to $50 \%$ of abortions and stillbirths, respectively in ovines all over the world (Aljumaah and Hussein, 2012). In small ruminants, the infection is mostly asymtamatic, except still births in the last trimester of gestation. The healthy ewes get the infection from the breeding rams and plays an important role in the transmission of disease. In addition, wild animals serve as potential reservoirs and play an important role in environmental contamination and spread of $C$. abortus (Hotzel et al., 2004). Seroprevalence of chlamydial infection is essential in monitoring the occurrence or presence of disease. Several diagnostic techniques have been in use worldwide since a decade to predict the chlamydial infections as it has been one of the economically important infections of livestock and of its zoonotic nature (Bandyopadhyay et al., 2009). Isolation of the microorganism remains a difficult and time-consuming task. Thus serological methods like ELISA can effectively confirm the disease. Hence in the present study, the seroprevalence for the chlamydial infection is carried out by preforming indirect ELISA

In the present study, a total of 28 serum samples from sheep were collected with a history of abortions and retained placenta cases in Krishna district of Andhra Pradesh. The blood samples were collected aseptically in vaccutainers and allowed to clot for the separation of serum. The sera were aliquoted in $2 \mathrm{~mL}$ vials and preserved at $-40^{\circ} \mathrm{C}$ until further use. The samples were collected from different villages of Krishna district (Table. 1) during the months of August 2016 to January 2017. 
Seroprevalence of chlamydophila infection in sheep

Table 1. Details of the serum samples collected randomly from various villages of Krishna District

\begin{tabular}{lllc}
\hline S.No & Village & Mandal & Number of samples collected \\
\hline 1 & Korukollu & Kalidindi & 5 \\
2 & Bobbiligudem & Kalidindi & 9 \\
3 & Gollagudem & Kalidindi & 4 \\
4 & Jammigolvepalli & Pamarru & 7 \\
5 & Nimmakuru & Pamarru & 3 \\
\hline & & Total & $\mathbf{2 8}$ \\
\hline
\end{tabular}

ELISA procedure: The detection of antibody levels to Chlamydophila abortus infection in the test serum samples was estimated by indirect ELISA test kit (IDEXX Chlamydiosis total Ab kit, Ireland). In brief, microwells coated with Chlamydophila abortus specific antigen were added with 1: 10 diluted test sera with dilution buffer. Positive and negative controls were also placed that were provided in the kit. The ELISA plate was incubated at $20^{\circ} \mathrm{C}$ for $45 \mathrm{~min}$. The wells were emptied and the microwells were washed thrice with $200 \mu \mathrm{L}$ wash solution. Then $100 \mu \mathrm{L}$ of diluted conjugate (1:10) was added and incubated at $20^{\circ} \mathrm{C}$ for 30 min. The wells were emptied and washed thrice with $200 \mu \mathrm{L}$ of wash solution. Substrate solution of OPD (OPhenylenediamine dihydrochloride) @ $100 \mu \mathrm{L}$ was added to each well and incubated for $15 \mathrm{~min}$ at $20^{\circ} \mathrm{C}$ in dark. Finally, the reaction was stopped by adding
$100 \mu \mathrm{L}$ of stopping solution and the results were read with optical density at a wave length 450nm in an ELISA reader (Thermo, 51119000, Germany ).

Interpretation for each sample was done by calculating the $\mathrm{S} / \mathrm{P}$ percentage $(\mathrm{S} / \mathrm{P} \%)$

$\mathrm{S} / \mathrm{P} \%=\frac{\mathrm{OD} \text { of the sample }}{\text { OD of the positive control }} \times 100$

Samples presenting a $(\mathrm{S} / \mathrm{P} \%)$ :

- Less than or equal to $50 \%$ are considered negative

- Less than $60 \%$ and greater than $50 \%$ are considered doubtful

- Greater than or equal to $60 \%$ are considered positive

The ELISA results revealed seropositivity of $14 \%(4 / 28)$ in sheep for chlamydial antibodies. Only four sera samples of sheep (one from Korukollu and three from Bobbiligudem village) produced a $\mathrm{S} / \mathrm{P}$ percentage of greater than $60 \%$. Among all 
the villages, highest incidence of the chlamydial infection was seen in Bobbiligudem with three positive sera. Statistical analysis was carried out to find out any significant difference in the prevalence of disease by using Chi-square test. Bobbiligudem had the highest prevalence of chlamydial infection with three positive cases out of nine serum samples collected.

Serological tests play a significant role in detecting the presence of antibodies against the chlamydial infection despite various other tests like isolation, immunohistochemistry and highly sensitive polymerase chain reaction (Didugu et al., 2016). Indirect ELISA is easy to perform and does not require highly qualified persons. The other methods are cumbersome and require skilled persons. It is very difficult to diagnose the infection in the clinical cases as the infection is more asymptamatic and only abortions are the characteristic pathognomic clinical sign that could be detected. But abortions in livestock are caused by a large number of reasons and it is difficult to differentiate as chlamydial infection. Hence, indirect ELISA is the best method with high specificity without any cross reactions and is less cumbersome (Gokce et al., 2007).

Earlier, several authors reported seroprevalence of chlamydiosis among large ruminant species, viz. cattle using ELISA that revealed the seroprevalence rates as zero percent (Ozturk et al., 2012), $4.75 \%$ (Wilson et al., 2012), $8.33 \%$ (Igayara-Souza et al., 2004), 26.92\% (Gokce et al., 2007), 35\% (Bandyopadhyay et al., 2009 ) and 68.18\% (Didugu et al., 2016). In the present study, the chlamydial infection in small ruminant species, e.g. sheep was $14 \%$ and the reports of seroprevalence of other authors were 7.52\% (Aljumaah and Hussein, 2012), $4.55 \%$ (El-Razik et al., 2011), 5.4\% (Otlu et al., 2007) and $11.7 \%$ (Cislakova et al., 2007). Statistical analysis was carried out using Chi-square test to study seroprevalence of Chlamydophila abortus in relation to village affected. Highest incidence of chlamydial infection was observed in Bobbilligudem and the differences in occurrence of the disease was significant as the $\mathrm{p}$ value is less than 0.05 . In the present study, the seroprevalence in sheep was high and it might be due to the low sample number and high susceptibility of infection. The presence of infection in sheep indicates that detailed study should be performed in future with large number of samples to explore the real status of chlamydial infection of Krishna district, Andhra Pradesh.

Studies on seroprevalence of chlamydial antibodies in livestock using reliable serodiagnostic methods like indirect ELISA 
aids in identifying infected and carrier animals, and also in assessing the status of infection in a particular geographical studied area, so that appropriate preventive measures can be undertaken for minimizing the disease and to reduce zoonosis.

\section{REFERENCES}

Aljumaah RS and Hussein MF, 2012. Serological prevalence of ovine and caprine chlamydophilosis in Riyadh region, Saudi Arabia. African J Microbiol Res, 6(11): 2654-2658

Bandyopadhyay S, Sasmal D, Biswas TK, Samanta I and Ghosh MK, 2009. Serological evidence of antibodies against Chlamydophila abortus in freeranging yak (Poephagus grunniens) in Arunachal Pradesh, India. Revue scientifique et technique (International Office of Epizootics), 28(3): 1051-1055

Cislakova L, Halanova M, Kovacova D and Stefancikova A, 2007. Occurrence of antibodies against Chlamydophila abortus in sheep and goats in the Slovak Republic. Ann Agri Environ Med, 14: 243-245

DeGraves FJ, Kim T, Jee J, Schlapp T and Hehnen HR et al., 2004. Reinfection with Chlamydophila abortus by uterine and indirect cohort routes reduces fertility in cattle preexposed to Chlamydophila. Infect Immun, 72(5): 2538-2545

Didugu H, Narasimha Reddy E, Ramanipushpa RN, Ramaraju SSB and Reddy MV, et al., 2016. Serological investigation of

\section{ACKNOWLEDGEMENTS}

The authors are thankful to the Associate Dean, NTR CVSc., Gannavaram, SVVU University, Tirupati for providing the facilities to carry out the work.

chlamydial infection among ruminants in Krishna district of Andhra Pradesh, India J Liv Sci, 7: 187-191

El-Razik KA, AL-Humiany AA, Ahmed WM, Barakat AM and EL fadaly HA, 2011. Investigations on non brucella abortifacients in small ruminants in Saudi Arabia with emphasis on zoonotic causes. Global Vet, 6(1): 25-32

Everett KD, Bush RM and Andersen AA, 1999. Emended description of the order Chlamydiales, proposal of Parachlamydiaceae fam. nov. and Simkaniaceae fam. nov., each containing one monotypic genus, revised taxonomy of the family Chlamydiaceae, including a new genus and five new species and standards for the identification of organisms. Int J Sys Bacteriol, 49(2): 415-440

Gokce H, Kacar C, Genc O and Sozmen M, 2007. Seroprevalence of Chlamydophila abortus in abortingewes and dairy cattle. Bull Vet Ins Pulawy, 51: 9-13

Gomes MJPO, Wald VBO, Machado RDO and Silveira MC, 2001. Isolam entode Chlamydiapsittaci em touros com vesiculite seminal, no Rio Grande do Sul. A Hora Veterinária, 119: 43-46 
Hotzel H, Berndt A, Melzer F and Sachse K, 2004. Occurrence of Chlamydiaceae spp. in a wild boar (Susscrofa L.) population in Thuringia (Germany). Vet Microbiol, 103(1): 121-126

Igayara-Souza CA, Genovez, ME, Ferreira F, Paulin LM and Scarcelli E et al., 2004. Ocorrência de anticorpos antiChlamydophila em bovinos e sua relação comdistúrbios reprodutivos. Revista brasileira de reprodução animal, 28(1): 28-33

Koehler L, Nettelnbreker E, Hudson AP, Ott N and Gerard HC et al., 1997. Ultrastructural and molecular analyses of the persistence of Chlamydia trachomatis (serovar K) in human monocytes. Microbial Pathogen, 22(3): 133-142

Markey B, 2011. Chlamydial infection in cattle: The burden of proof? Vet J, 189(3): 246247

Otlu S, Sahin M, Unver A and Celebi O, 2007. Detection of Brucella melitensis and Chlamydophila abortus antibodies. Bull
Vet Inst Pulawy, 51: 493-495

Ozturk D, Kale M, Pehlivanoglu F, Hasýrcýoglu S and Turutoglu H, 2012. Evaluation for some bacterial and viral abortions of dairy cattle farms in Burdur district of Turkey. Kafkas Univ Vet Fak Derg, 18 (2): 255-258

Rekiki A, Sidi-Boumedine K, Souriau A, Jemli $\mathrm{J}$ and Hammami S et al., 2002. Isolation and characterisation of local strains of Chlamydophila abortus (Chlamydia psittaci serotype 1) from Tunisia. Vet Res, 33(2): 215-222

Rodolakis A and Mohamad KY, 2010. Zoonotic potential of Chlamydophila. Vet Microbiol, 140(3): 382-391

Twomey DF, Griffiths PC, Hignett BC and Martin TP 2003. Suspected chlamydial polyarthritis in a calf in the UK. Vet Rec, 152(11): $340-340$

Wilson K, Sammin D, Harmeyer S, Nath M and Livingstone M et al., 2012. Seroprevalence of chlamydial infection in cattle in Ireland. Vet J, 193(2): 583-585 